\title{
Determination of Hydraulic Characteristics Using Electrical Resistivity Methods - A Case Study from Vanur Watershed, Villupuram District, Tamil Nadu
}

\author{
${ }^{1}$ V.Arulprakasam, ${ }^{2}$ R. Sivakumar, and ${ }^{2}$ B.Gowtham \\ ${ }^{1}$ Central Ground Water Board, CR, Nagpur \\ ${ }^{2}$ Department of Geology, Presidency College, Chennai
}

\begin{abstract}
In groundwater investigations, various parameters of the aquifers are conventionally estimated through long-duration aquifer performance test in wells. In multi-aquifer systems, a number of pumping and observation wells are required for realistic assessment of aquifer characteristics. The expenditure involved in construction and testing of wells often impose constraints on testing individual aquifer zones in such cases. Empirical relations established between aquifer parameters such as hydraulic conductivity $(K)$ / Transmissivity (T) and parameters computed from geophysical investigations such as electrical resistivity / Transverse resistance could be used to estimate the aquifer parameters of different aquifer zones. An attempt has been made in the present study to assess the hydraulic conductivity of Vanur watershed of Villupuram district, Tamil Nadu using surface electrical resistivity surveys. The aquifer system consists of Alluvium, Sandstone and Limestone with intercalations of clay. The bulk porosity of the aquifers has been estimated by using Archie's equation and it ranges from 0.19 to 0.39 . Empirical relations have been established between geophysical and aquifer parameters for the study area and the same have been validated with the results of pumping test.
\end{abstract}

\section{Introduction}

There is an ever-increasing demand for fresh water resources to meet the requirements for Industrial, Agricultural and domestic sectors. The over-exploitation of groundwater resources and its contamination have put a several stress on the available ground water resources in the country. Geophysical methods are playing an increasingly important role in groundwater investigation. Of all surface geophysical methods, electrical resistivity methods have successfully applied. It reduces the amount of required test drilling substantially by allowing a more judicious selection of test holes. In most investigations, a combination of optimum drilling and geophysical measurements will provide a viable solution.

One of the common methods for evaluating aquifer characteristics is the use of pumping test but at times due to logistic and other problems, it is not possible to carry out long duration tests, which are necessary for a better understanding of aquifer characters. Surface electrics in which large volumes of earth materials are covered, offer an alternative approach for the estimation of hydraulic characteristics at aquifer scale. In the past surface resistivity methods have been routinely used to obtain qualitative aquifer information. Since late sixties resistivity determined from surface measurements have been used to estimate aquifer properties including specific yield, hydraulic conductivity and transmissivity. In the present study an attempt has been made to assess the hydraulic characteristics using surface electrical methods in Vanur watershed of Villupuram district, Tamil Nadu.

\section{Study Area}

Vanur watershed of Villupuram district is bounded in the North by Tindivanam and Marakkanam blocks, South by Pondicherry Union Territory and Kandamangalam block, west by Vikravandi and Mailam blocks and East by Bay of Bengal and Pondicherry Union Territory. It falls within the co-ordinates of Latitude $11^{\circ} 55^{\prime} 05^{\prime \prime}$ to $12^{\circ} 02^{\prime} 10^{\prime \prime}$ and Longitude $79^{\circ} 35^{\prime} 10^{\prime \prime}$ and $79^{\circ} 51^{\prime} 15^{\prime \prime}$ of Survey of India Top sheets 57P/12, 16 and $58 \mathrm{M} / 13$. The areal extent of the block is $454.87 \mathrm{sq} . \mathrm{kms}$ (Fig.1). Sankaraparani River traverses at South western part, Nallavur Ar. Traverses through the central portion of the block.

Vanur watershed enjoys a typical semi-arid climate. It receives average annual rainfall of about 1220 $\mathrm{mm}$. About 62 percent of the annual rainfall is received during the Northeast monsoon during November to December, whereas about 34 percent is received during southwest monsoon during June to August. The area receives rain for about 60 days in a year. The area comprised by coastal alluvium, Cuddalore sandstone, Vanur sandstone, limestone and Charnockite. The Vanur sandstone formation, which is the major aquifer system in the area, is exposed in a number of places within the block. Seawater intrusion in groundwater has been reported in Vilvanatham and Royallai villages from previous studies, which lie in northeast part of the study area. 


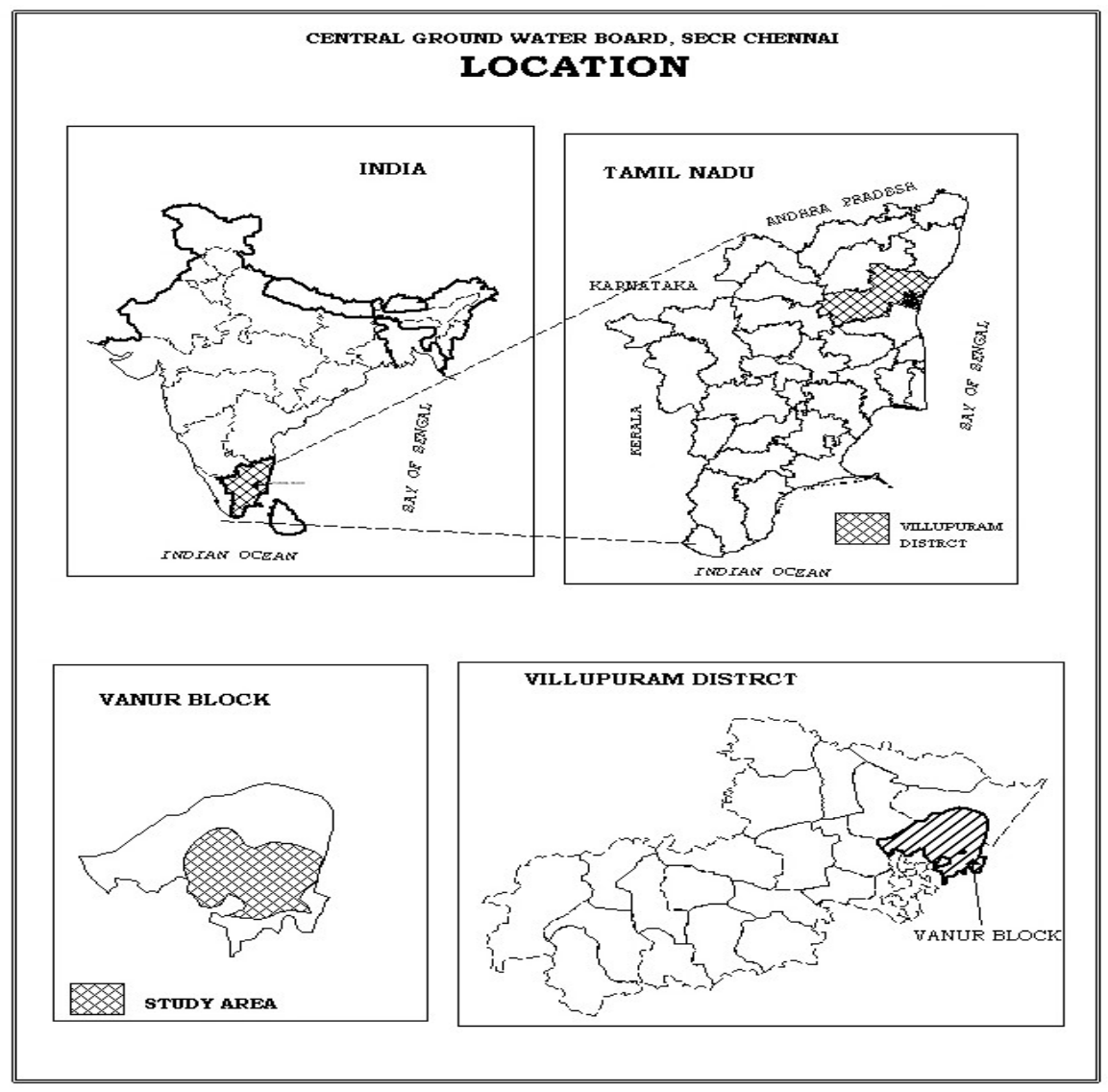

Fig 1: Location Map

\section{Data Analysis}

Since late sixties resistivity determined from surface measurements have been used to estimate aquifer properties including yield, hydraulic conductivity and transmissivity. Ungemach et al (1969) correlated transmissivity determined from the results of six pumping tests in the Rhine aquifer with transverse unit resistance. Kelly (1977) and Kosinski and Kelly (1981) correlated saturated thickness resistivity obtained from pumping tests in south Rhode Island, USA. Mazac and Landa (1979) analyzed data from Czechoslovakia and concluded that relation between aquifer transmissivity and either transverse resistance or longitudinal conductance is possible for both direct and inverse material-level correlation between resistivity and hydraulic conductivity. Frohlich and Kelly (1985) and Huntley (1986) generally confirmed the wider applicability of direct relations between apparent formation factor and hydraulic conductivity for granular aquifers and transverse resistance and hydraulic transmissivity in glacial aquifers. Singhal et al., (1998) concluded that in an alluvial area, where Darcy flow is deemed to be valid, hydraulic conductivity and transmissivity of aquifers can be estimated with reasonable accuracy at aquifer level by using relations between hydraulic and resistivity properties. Senthil kumar et al., (2001) has brought out the relationship between hydraulic properties and resistivity parameters of the Thiruvanmiyur - Muttukadu alluvial aquifer. Majumdar et al., (2005) have stated that estimation of hydraulic conductivity, transmissivity, specific capacity and porosity are feasible from surface resistivity measurements and useful relations can be developed between aquifer resistivity with aquifer hydraulic properties of alluvial aquifers. Sriniwas et al., (2006) have developed the mathematical equation to estimate hydraulic aquifer property from surface electrical measurement. Ekwe et al., (2006) have also used the established relationship between aquifer characteristics and geoelectric parameters to estimate hydraulic conductivity and transmissivity values of all the sounding locations including areas where boreholes were non existent.

An attempt has been made in the present study to estimate hydrogeological parameters Vanur watershed which is an sedimentary terrain using surface electrical resistivity surveys. The evaluation of aquifer characteristics through the analysis of pumping test data has become a standard procedure in the evaluation of groundwater resource potential. Ten wells were selected in Vanur formation. The available pumping test data of the area was analyzed for evaluation of aquifer characteristics like Transmissivity (T) and hydraulic conductivity (K). All the pumping test data were analyzed using Theiss type curve as a confined aquifer. Water samples were collected to determine the formation factor and three empirical relations were estimated. 


\subsection{Relation between Aquifer Parameters and Resistivity Data}

For estimation of porosity of unconsolidated sediments, Archie (1942) established a relation between aquifer and water resistivity and it is termed as 'Formation Factor' (Ff).

$$
F f=\frac{R o}{R w}
$$

Where, 'Ro' is the resistivity of the aquifer, and

' $R w^{\prime}$ ' is the resistivity of the water.

Doveton (1986) had modified the Archie's equation and established the relation between formation factor and porosity of aquifer material as mentioned below:

$$
F f=\frac{1.0}{\phi 1.3}=\frac{R 0}{R w}
$$

From the above-mentioned relation, ' $\varphi$ ' is the porosity, 'Ro' is the aquifer resistivity and 'Rw' is the pore-water resistivity measured from well samples. By applying the above equation, the range of the porosity is found between 0.19 to 0.39 .

\subsection{Relation between Aquifer Hydraulic Conductivity (K) and Apparent Formation Factor (Ff)}

Empirical relations between (Ff) and (K) can be represented by a log log relation (Mazak et al., 1985) as

$$
K=A \times F f m
$$

Where, 'A' and ' $m$ ' are empirically derived constants.

The hydraulic conductivity and formation factor of unconfined aquifer at nine sites of the test area were plotted on a log-log graph (Fig.2) and using regression the equation of straight line was found to be giving values of $\mathrm{K}$, close to the field values with Root Mean Square $(\mathrm{RMS})=0.454$.

$$
K=0.441 \times(F f) 0.72
$$

This has established a power relationship between hydraulic conductivity and formation factor on the lines suggested by Mazak et al. (1985), Huntley (1986) and Singhal (1998).

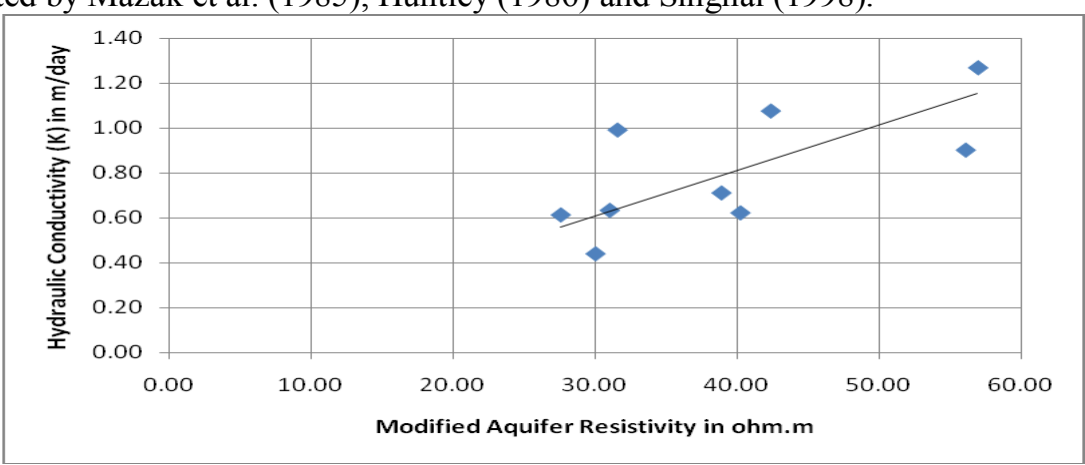

Fig. 2. Aquifer Hydraulic Conductivity (K) versus Apparent Formation Factor (Ff)

\subsection{Relation between Hydraulic Conductivity and Modified Aquifer Resistivity}

Modified aquifer resistivity, is the aquifer resistivity modified according to Singhal (1998). In coastal areas, particularly, where interstitial water resistivity varies laterally as well as vertically, the transverse resistance or longitudinal conductance is calculated with modified resistivity to normalize the aquifer resistivity and accommodate the quality variation on transmissivity or hydraulic conductivity is not affected by the EC of water, but transverse resistance or longitudinal conductance is dependent of water EC. The modification factor is the ratio of average aquifer water resistivity and aquifer water resistivity.

$$
\rho^{\prime}=\rho \times\left(\frac{\rho r w}{\rho w}\right)
$$

Where, $\rho$ ' is the modified aquifer resistivity,

$\rho^{\prime} w$ is the average aquifer water resistivity and $\rho w$ is the aquifer water resistivity.

The empirical relationship between hydraulic conductivity and modified aquifer resistivity indicates that hydraulic conductivity increases with increase in modified aquifer resistivity (Fig-3). The equation of fitted regression line is

$$
K=0.041\left(\rho^{\prime}\right) 0.645
$$

It also gives values of $\mathrm{K}$ close to the field values with Root Mean Square $(\mathrm{RMS})=0.454$. 


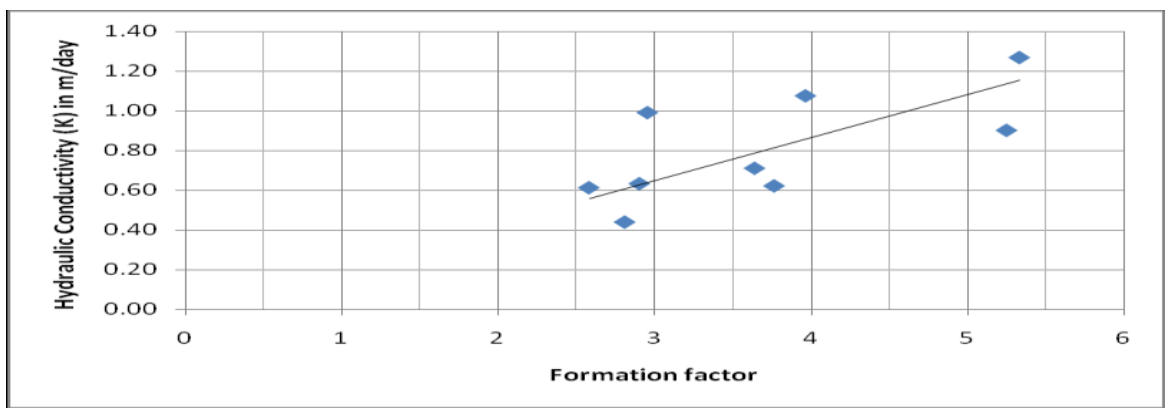

Fig.3. Hydraulic Conductivity versus Modified Aquifer Resistivity

\subsection{Relation between transmissivity and transverse resistance}

An approach has been attempted to find out aquifer transmissivity and transverse resistance (Fig. 4). The figure gives that Transmissivity of aquifer (T) increases with increase in Transverse resistance (R). The linear regression relationship is obtained as:

$$
T=0.53 \times R
$$

The Root Mean Square (RMS) is measured as 0.823 . The modified Transverse resistance can also be computed by the following relation and is given in table 1 .

$$
R^{\prime}=R \times\left(\frac{\rho r w}{\rho w}\right)
$$

Where, $R^{\prime}$ is the modified transverse resistance, $R$ is the transverse resistance.

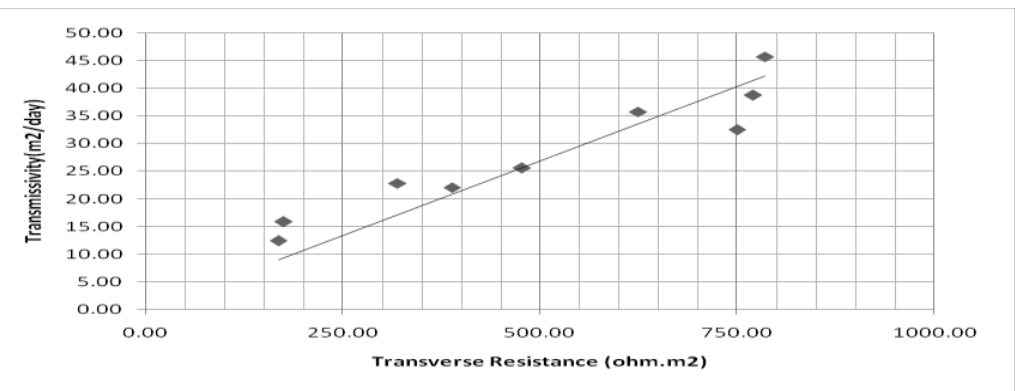

Fig.3 Transmissivity versus Transverse resistance

\begin{tabular}{|c|c|c|c|c|c|c|c|c|c|c|}
\hline \begin{tabular}{l|} 
SI. \\
No
\end{tabular} & Evaluated parameters & $\begin{array}{c}\text { Kattarampa } \\
\text { kkam }\end{array}$ & \begin{tabular}{c|}
$\begin{array}{c}\text { Nes } \\
\text { al }\end{array}$ \\
\end{tabular} & \begin{tabular}{|c|}
$\begin{array}{c}\text { Pulichchapa } \\
\text { llam }\end{array}$ \\
\end{tabular} & $\begin{array}{c}\text { Nainarpala } \\
\text { yam }\end{array}$ & $\begin{array}{c}\text { Van } \\
\text { ur } \\
\end{array}$ & $\begin{array}{c}\text { Abhiramp } \\
\text { attu }\end{array}$ & \begin{tabular}{|c|}
$\begin{array}{c}\text { Vilvanat } \\
\text { tam }\end{array}$ \\
\end{tabular} & $\begin{array}{c}\text { Anapak } \\
\text { kam }\end{array}$ & $\begin{array}{c}\text { Tailapu } \\
\text { ram }\end{array}$ \\
\hline 1 & $\begin{array}{l}\text { Thickness of the aquifer } \\
\text { tapping (b) } \mathrm{m}\end{array}$ & 36 & 36 & 36 & 36 & 36 & 36 & 36 & 36 & 36 \\
\hline 2 & $\begin{array}{l}\text { Transmissivity } \\
\text { (T) } \mathrm{m}^{2} / \text { day }\end{array}$ & 25.61 & \begin{tabular}{c|}
22.4 \\
1 \\
\end{tabular} & 15.83 & 35.72 & \begin{tabular}{c|}
45.7 \\
2 \\
\end{tabular} & 38.77 & 22.81 & 22.08 & 32.49 \\
\hline 3 & $\begin{array}{l}\text { Hydraulic conductivity } \\
(\mathrm{K}=\mathrm{T} / \mathrm{b}) \mathrm{m}^{2} / \text { day }\end{array}$ & 0.71 & 0.62 & 0.44 & 0.99 & 1.27 & 1.08 & 0.63 & 0.61 & 0.90 \\
\hline 4 & $\begin{array}{l}\text { Resistivity aquifer } \\
(\rho o) \text { ohm.m }\end{array}$ & 34 & 29.8 & 31.8 & 38.9 & 69.9 & 35.2 & 27.8 & 38.9 & 40.41 \\
\hline 5 & $\begin{array}{l}\text { Transverse resisivity } \\
\left.\left(\rho_{\mathrm{t}}=\left(\sum \rho_{1} \mathrm{~h} 1\right) / \mathrm{H}\right)\right)\end{array}$ & 11.16 & 4.07 & 8.99 & 12.68 & 8.64 & 8.89 & 7.81 & 11.22 & 5.35 \\
\hline 6 & $\begin{array}{l}\text { Longitudinal resistivity } \\
\left(\rho_{1}=\mathrm{H} /\left(\sum \mathrm{h} / \rho 1\right)\right)\end{array}$ & 9.18 & 3.23 & 4.81 & 7.29 & 6.04 & 6.92 & 2.73 & 8.15 & 5.78 \\
\hline 7 & $\begin{array}{l}\text { Electrical Anisotropy } \\
(\lambda=\sqrt{\rho t} / \rho \mathrm{l})\end{array}$ & 1.10 & 1.12 & 1.37 & 1.32 & 1.20 & 1.13 & 1.69 & 1.69 & 0.96 \\
\hline 8 & $\begin{array}{l}\text { Resistivity of water sample } \\
\text { at } 25^{\circ} \mathrm{C}\left(\rho_{\mathrm{w}}\right)\end{array}$ & 9.34 & 7.91 & 11.31 & 13.16 & $\begin{array}{c}13.1 \\
1\end{array}$ & 8.87 & 9.57 & 15.06 & 7.69 \\
\hline 9 & $\begin{array}{l}\text { Average aquifer water } \\
\text { resistivity }\left(\rho_{\mathrm{w}}^{\prime}\right) \text { ohm.m }\end{array}$ & 10.67 & \begin{tabular}{c|}
10.6 \\
7 \\
\end{tabular} & 10.67 & 10.67 & \begin{tabular}{c|}
10.6 \\
7 \\
\end{tabular} & 10.67 & 10.67 & 10.67 & 10.67 \\
\hline 10 & $\begin{array}{l}\text { Modified aquifer } \\
\text { resistivty }\left(\rho^{\prime}=\rho 0^{*}\left(\rho_{\mathrm{w}}^{\prime} / \rho_{\mathrm{w}}\right)\right.\end{array}$ & 38.85 & \begin{tabular}{c|}
40.1 \\
9 \\
\end{tabular} & 29.99 & 31.54 & \begin{tabular}{c|}
66.9 \\
0 \\
\end{tabular} & 42.32 & 30.99 & 27.56 & 56.03 \\
\hline 11 & $\begin{array}{l}\text { Apparent formation } \\
\text { factor }\left(\mathrm{FF}=\rho \mathrm{O} / \rho_{\mathrm{w}}\right)\end{array}$ & 3.64 & 3.77 & 2.81 & 2.96 & 5.33 & 3.97 & 2.91 & 2.58 & 5.25 \\
\hline 12 & $\begin{array}{l}\text { Transverse } \\
\text { resistance }\left(\mathrm{TR}=\sum \rho 1 \mathrm{~h} 1\right)\end{array}$ & 477.60 & \begin{tabular}{c|}
167. \\
89 \\
\end{tabular} & 174.72 & 624.56 & $\begin{array}{c}785 . \\
80 \\
\end{array}$ & 770.50 & 319.50 & 388.43 & 749.91 \\
\hline 13 & $\begin{array}{l}\text { Modified Transverse } \\
\text { resistance }\end{array}$ & 545.72 & \begin{tabular}{c|}
226. \\
41
\end{tabular} & 164.79 & 506.41 & $\begin{array}{c}639 . \\
66\end{array}$ & 926.43 & 356.21 & 275.17 & 1040.09 \\
\hline
\end{tabular}

Table 1. Results of Electrical resistivity data and Pumping Test for the Vanur Watershed 


\begin{tabular}{|c|c|c|c|c|c|c|c|c|c|c|}
\hline & $\left(\mathrm{R}^{\prime}=\mathrm{R}^{*} \rho_{\mathrm{w}}^{\prime} / \rho_{\mathrm{w}}\right)$ & & & & & & & & & \\
\hline 14 & Porosity & 0.27 & 0.27 & 0.36 & 0.34 & 0.19 & 0.25 & 0.34 & 0.39 & 0.19 \\
\hline & \multicolumn{10}{|c|}{ Results of Computered Hydraulic Parameters from Equations } \\
\hline 1 & $\begin{array}{l}\text { Hydaulic conductivity } \mathrm{K}= \\
0.041\left(\rho^{\prime}\right)^{0.645}\end{array}$ & 1.59 & 1.65 & 1.23 & 1.29 & 2.74 & 1.74 & 1.27 & 1.13 & 2.30 \\
\hline 2 & $\begin{array}{l}\text { Hydaulic conductivity } \mathrm{K}= \\
0.44 \text { (Ff) } \\
0.72\end{array}$ & 1.60 & 1.66 & 1.24 & 1.30 & 2.35 & 1.75 & 1.28 & 1.14 & 2.31 \\
\hline 3 & $\begin{array}{l}\text { Transmissivity }(\mathrm{T}=0.053 * \mathrm{R}) \\
\mathrm{m}^{2} / \text { day }\end{array}$ & 25.31 & 8.90 & 9.26 & 33.10 & $\begin{array}{c}41.6 \\
5\end{array}$ & 40.84 & 16.93 & 20.59 & 39.75 \\
\hline 4 & $\begin{array}{l}\text { Transmissivity }(\mathrm{T}= \\
\left.0.047^{*} \mathrm{R}^{\prime}\right)\end{array}$ & 25.65 & $\begin{array}{c}10.6 \\
4\end{array}$ & 7.74 & 23.80 & $\begin{array}{c}30.0 \\
6\end{array}$ & 43.54 & 16.74 & 12.93 & 48.88 \\
\hline
\end{tabular}

\section{Conclusion}

From the above study, estimation of hydraulic conductivity, transmissivity, porosity and formation factor are feasible from surface resistivity measurements and useful relations can be developed between aquifer resistivity with aquifer hydraulic properties of aquifers. Such analysis can be used for groundwater resource assessment of the area.

As the aquifer usually consists of anisotropic and inhomogeneous materials, the empirical relations developed in this study area are not expected to be applicable to other areas. However, the methodology is valid for predicting aquifer properties.

\section{Acknowledgements}

The authors are grateful to Shri. Sushil Gupta, Chairman, Central Ground Water Board for his permission to publish this paper. They express their sincere thanks to Dr.P. K. Jain, HO of CGWB, CR, Nagpur, Dr. R. Sivakumar, Associate Professor and Head, Department of Geology, Presidency College, Chennai for their able guidance during preparation of this paper. Assistance rendered by the officers and staff of CGWB, CR, Nagpur the field surveys as well as preparation of this paper is gratefully acknowledged.

\section{References}

[1]. Archie, G. E., 1942. The electrical resistivity $\log$ as an aid in determining some reservoir characteristics. Am. Inst. Min. Met. Pet. Eng. Tech. Rep., New York, 1422p.

[2]. Doveton. J. A. 1986, Log Analysis of subsurface geology. John willey and sons. Inc. New Yark, pp.258-263.

[3]. Ekwe, A.C., Onu, N.N and Onuoha., K.M., 2006. Estimation of aquifer hydraulic characteristics from electrical sounding data: the case of middle Imo River basin aquifers, south- eastern Nigeria. Journal of Spatial Hydrology. Vol.6, No.2, pp.121-132.

[4]. Forhlich, R., and Kelly, W. E., 1985. The relation between transmissivity and transverse resistance in a complicated aquifer of glacial outwash deposits. Jour. Of Hydrology V. 79. pp. 215-219.

[5]. Huntley, D., 1986. Relation between permeability and electrical resistivity in granular aquifer. Ground Water. V. 24. pp.466-475.

[6]. Kelly. W. E., 1977. Geoelectrical sounding for estimating aquifer hydraulic conductivity. Ground Water 15(6), pp.420-424.

[7]. Kosinski, W. K and Kelly, W. E., 1981. Geoelectrical sounding for predicting aquifer properties. Ground Water 19(2), pp.163-171.

[8]. Mazac. O. and Landa, I., 1979. On determination of hydraulic conductivity and transmissivity of granular aquifers by vertical electrical sounding. Jour. Geol. Sci., (16), pp.123-139. (In Czech).

[9]. Mazak. O., Kelly. W.E and Landa, I., 1985. A Hydrogeological model for relations between electrical and hydraulic properties of aquifers. Jour. Hydrology. V.79. pp.1-19.

[10]. Majumdar, R. K and Pal, S. K., 2005. Geoelectric and Borehole lithology studies for groundwater investigation in alluvial aquifers of Munger district, Bihar, Journal Geological Society of India, v. 66. pp.463-475.

[11]. Senthil Kumar. M., Gnanasunder. G and Elongo, L, 2001. Geophysical Studies to Determine Hydraulic Characteristics of an Alluvial Aquifers. Jour. Environmental Hydrology. V 9 paper -15. 7p.

[12]. Sriniwas and Delima, O. A.L., 2006. Correlating Electrical and hydraulic conductivity of a General aquifer model: Concept and application. Jour. GSI, v. 67. pp.732-736.

[13]. Singhal, D.C., Sriniwas., Shakeel, M and Adam, E.M., 1998. Estimation of Hydraulic characteristics of Alluvial Aquifers from Electrical Resistivity data. Jour. Geological Survey of India V. 51, pp.461-470.

[14]. Ungemach. P., F. Mostanghimi and A. Duprat; (1969). Emphasis in determination of Transmissivity coefficient and application in nappe alluvial aquifer Rhine. Bult. Int. Assoc.Sci. Hydrol.XIV (3), pp.169-190. 